\title{
Deskripsi Analitik atas Gerak Pertumbuhan dan Perkembangan Institusi Pendidikan Tinggi Muhammadiyah di Sulawesi Tenggara
}

\author{
Muhammad Alifuddin ${ }^{1}$, Samritin $^{2 *}$, Rosmini ${ }^{1}$ \\ ${ }^{1}$ IAIN Kendari, Indonesia \\ 2Universitas Muhammadiyah Buton, Indonesia \\ *Korespondensi: samritin75@gmail.com
}

\begin{tabular}{|c|c|}
\hline & Abstrak \\
\hline $\begin{array}{c}\text { Diterima } 11 \\
\text { Februari } 2022 \\
\text { Disetujui } 25 \\
\text { Februari } 2022 \\
\text { Dipublikasikan } 26 \\
\text { Februari } 2022 \\
\end{array}$ & $\begin{array}{l}\text { Penelitian ini adalah upaya mendeskripsikan secara analitik tentang } \\
\text { pertumbuhan dan perkembangan Perguruan Tinggi Muhammadiyah (PTM) } \\
\text { di Sulawesi Tenggara. Data-data yang digunakan dalam tulisan ini selain } \\
\text { bersumber dari hasil wawancara, pengamatan dan telaah dokumen. } \\
\text { Seluruh data yang diperoleh dianalisis dengan menggunakan paradigma } \\
\text { Miles dan Huberman. Penelitian ini menyimpulkan: (1) secara historis } \\
\text { pertumbuhan dan perkembangan PTM di Sultraawesi tidak dapat } \\
\text { dilepaskan dengan dinamika politik yang sedang berkembang. Lima PTM } \\
\text { yang kini eksis, seluruhnya terwujud dalam suasana politik yang terbuka }\end{array}$ \\
\hline $\begin{array}{c}\text { Keywords: } \\
\text { Perkembangan; } \\
\text { Institusi } \\
\text { Pendidikan; } \\
\text { Muhammadiyah }\end{array}$ & $\begin{array}{l}\text { dan atau berbasis pada penilian yang fair, jauh dari praktik politik } \\
\text { sektarian/partisan; (2) selain faktor keterbukaan sistem politik, } \\
\text { Pertumbuhan dan perkembangan PTM di wilayah ini, terkait erat dengan } \\
\text { kemampuan SDM persyarikatan mengelola setiap momen sebagai } \\
\text { momentum untuk mewujudkan monumen infrastruktur akal budi. Hal } \\
\text { tersebut terjadi karena kekuatan jaringan Muhammadiyah, sifat kolektif }\end{array}$ \\
\hline $\begin{array}{l}\text { (c) } 2022 \text { The } \\
\text { Author(s): This is } \\
\text { an open-access } \\
\text { article distributed } \\
\text { under the terms of } \\
\text { the Creative } \\
\text { Commons } \\
\text { Attribution } \\
\text { ShareAlike (CC BY- } \\
\text { SA 4.0) } \\
\text { cc) }\end{array}$ & $\begin{array}{l}\text { budaya tersebut dapat dikelola dan dimobilisasi secara elegan sehingga } \\
\text { pada gilirannya memberi kekuatan bagi penggiat persyarikatan di wilayah } \\
\text { ini untuk tidak sekedar mengembangkan PTM yang telah ada tetapi juga } \\
\text { membangun PTM baru; (3) peningkatan jumlah dan kualitas PTM di Sultra } \\
\text { terjadi karena seluruh kekuatan modal sosial budaya plus jaringan luas } \\
\text { yang melekat pada persyarikatan Muhammadiyah dapat dikelola dan } \\
\text { diaktualkan melalui proses framing yang cerdas dan elegan. Melalui } \\
\text { sosialisasi, promosi dan pemasaran ide yang faktual memantik banyak } \\
\text { pihak untuk terlibat guna maju bersama Muhammadiyah untuk } \\
\text { membangun dan mengembangkan PTM di Sulawesi Tenggara. }\end{array}$ \\
\hline & $\begin{array}{l}\text { Abstract } \\
\text { This research is an attempt to describe analytically the growth and } \\
\text { development of Muhammadiyah Higher Education (MHE) in Southeast } \\
\text { Sulawesi. The data used in this paper are sourced from interviews, } \\
\text { observations, and document reviews. All data obtained were analyzed } \\
\text { using the Miles and Huberman paradigm. This study concludes: (1) } \\
\text { historically the growth and development of MHE in Southeast Sulawesi } \\
\text { cannot be separated from the political dynamics that are developing. The } \\
\text { five MHEs that now exist are all manifested in an open political } \\
\text { atmosphere and/or based on fair judgment, far from sectarian/partisan } \\
\text { political practices; (2) in addition to the openness factor of the political }\end{array}$ \\
\hline
\end{tabular}




\begin{abstract}
system, the growth and development of MHE in this region are closely related to the ability of the organization's HR to manage every moment as momentum to create a monument of cultural infrastructure. This happened because of the strength of the Muhammadiyah network, the collegial collective nature, and the strong philanthropic ethos of Muhammadiyah members. Socio-cultural capital can be managed and mobilized elegantly so that in turn it gives strength to organizational activists in this region to not only develop existing MHEs but also build new MHEs; (3) the increase in the number and quality of MHE in Southeast Sulawesi occurs because all the strengths of socio-cultural capital plus the extensive network attached to the Muhammadiyah organization can be managed and actualized through an intelligent and elegant framing process. Through socialization, promotion, and marketing of factual ideas, many parties are involved in advancing with Muhammadiyah to build and develop MHE in Southeast Sulawesi.
\end{abstract}

\title{
1. Pendahuluan
}

Pertumbuhan pendidikan tinggi di Indonesia terus meningkat, khususnya yang diselenggarakan oleh kelompok masyarakat. Muhammadiyah sebagai salah satu organisasi yang turut memberikan kontribusi tinggi dalam peningkatan jumlah pendidikan tinggi di Indonesia bahkan di dunia Internasional. Saat ini pendidikan tinggi yang didirikan oleh Muhammadiyah tersebar di berbagai wilayah Indonesia. Pendirian perguruan tinggi Muhammadiyah menjadi sebuah gerakan yang terus digaungkan seiring dengan kebutuhan masyarakat terhadap pendidikan juga perkembangan ilmu pengetahuan teknologi dan seni.

Gaung gerakan pendidikan tinggi Muhammadiyah, tidak hanya menggema pada wilayah seputaran Jawa, Sumatera dan Sulawesi, tetapi juga dan atau bahkan menyentuh sejumlah wilayah dengan penduduk mayoritas non muslim, seperti di Papua, NTT, Bali, Manado dll. Terbaru Muhammadiyah kini mendirikan lembaga pendidikan tinggi di negara tetangga Malaysia, mendirikan Universitas Siber Muhammadiyah (Sibermu) (PWMu, 2022). Magnet dari gerak Muhammadiyah dalam membangun institusi pendidikan tinggi juga merambah masuk ke wilayah Sulawesi Tenggara (Sultra). Data arsip Muhammadiyah menyebutkan, bahwa di wilayah ini kini telah berdiri 6 (enam) Perguruan Tinggi Muhammadiyah (PTM) dan seiring dengan perkembangan serta kebutuhan masyarakat akan layanan pendidikan tinggi, Muhammadiyah Sultra dalam dua atau maksimal tiga tahun mendatang berpotensi menambah jumlah 2 (dua) hingga 4 (empat) lembaga pendidikan tinggi yang dimililikinya (Aldjufri, wawancara).

Fenomena geliat pertumbuhan lembaga pendidikan tinggi Muhammadiyah di Sultra menarik untuk ditelaah, mengingat sumberdaya komunitas Muhammadiyah di wilayah ini secara kuantitatif terbilang minim. Selain itu, secara politik dalam kurun dua dasawarsa terakhir akses politik Muhammadiyah sangat terbatas. Hal ini sangat berpengaruh terhadap upaya pendirian PTM. Menurut Mustam (tokoh Muhammadiyah) pendirian lembaga pendidikan tinggi Muhammadiyah pada masa periode kedua kabinet Presiden SBY dan paruh lima tahun pertama periode kabinet Presiden Jokowi "terkesan" dipersulit (Mustam; wawancara). Pertanyaannya kemudian adalah mengapa dan bagaimana Muhammadiyah dapat tetap eksis mewujudkan cita-citanya membangun lembaga pendidikan tinggi, kendatipun berada dalam ruang sempit dan jauh dari akses politik. Kegelisahan akademik tersebut menjadi fokus telaah dari penelitian ini. 
Penelitian tentang eksistensi lembaga pendidikan Muhammadiyah sungguh telah banyak dilakukan oleh para peneliti, baik yang sifatnya general maupun kajian dengan setting back ground lokus/wilayah tertentu. Penelitian yang bersifat general antara lain dapat dilihat pada penelitian Syaifuddin (2020), Zarro (2020), demikian pula dengan penelitan Jannah (2019) serta Subarkah (2017). Empat penelitian tersebut mengulas tentang kepeloporan Muhammadiyah dalam mengintegrasikan nilai-nilai kecerdasan intelektual dan kematangan spiritual (Syaifuddin, 2020; Jannah, 2019), atau dengan kata lain kehadiran Muhammadiyah di dunia pendidikan memberikan perspektif baru, yaitu perspektif pendidikan bersifat integratif holistik (Zarro, 2020; Subarkah, 2017).

Selain dari sejumlah kajian di atas, terdapat sejumlah studi tentang sejarah lembaga pendidikan Muhammadiyah dengan setting lokus tertentu dan atau yang dilakukan di berbagai wilayah, misalnya penelitian Rohman (2019) di Sumatera Barat. Barni (2010) yang mengulas lembaga pendidikan Muhammadiyah di Kalimantan Selatan, demikikian dengan dengan penelitian Utama di Sumbawa Nusa Tenggara Barat (2017). Ketiga penelitian sebagaimana disebutkan setidaknya memiliki temuan mirip, yaitu bahwa lembaga pendidikan Muhammadiyah dapat eksis dan berkembang karena sifat kolektif kolegial yang sangat kuat tertanam dalam kultur sistem kerja organisasi Muhammadiyah. Pada sisi lain ditemukan hambatan baik yang bersifat internal (dari dalam organisasi) maupun aspek eksternal berupa akses dengan berbagai pihak luar yang kurang terbangun.

Sungguhpun sejumlah penelitian yang telah disebutkan fokus telaahnya mengarah pada eksistensi dan sejarah lembaga pendidikan Muhammadiyah sebagaimana tema penelitian ini, namun dari sisi lokus dan basis konseptual yang digunakan sangatlah berbeda. Penelitian ini adalah upaya mengungkap kepermukaan bagaimana komunitas Muhammadiyah berselancar dalam tarikan dinamika sosial politik dan budaya yang mengiringi perjuangan komunitas tersebut dalam membangun dan mengembangkan sayap amal usaha di bidang pendidikan tinggi di Sultra. Guna menjawab problem dan fenomena tersebut penelitian ini menggunakan alat analisis yang berbasis pada kerangka konsep gerakan sosial, sehingga dengan demikian menjadikan penelitian ini memiliki perbedaan dengan kajian sejenis yang telah dilakukan sebelumnya.

Giat pendidikan dipandang sebagai upaya untuk melakukan perubahan dalam konteks gerakan sosial berada dalam bingkai new social movement theory. Dalam konteks new social movement, gerakan sosial dimaknai sebagai tindakan kolektif yang berorientasi pada penentangan terhadap institusional authority (apakah ia berada dalam area politik seperti Negara atau lainnya seperti korporasi, agama atau pendidikan) atau bentuk bentuk otoritas budaya seperti sistem kepercayaan dan atau implementasi aktual dari sistem kepercayaan tersebut (Snow, 2004; Ritzers, 2004). Terdapat tiga unsur signifikan yang berpengaruh dalam gerakan social, yaitu: political opportunity spaces/Structure (ruang kesempatan politik), resource mobilization (mobilisasi sumber daya), dan social framing (pembingkaian sosial). Unsur pertama, Political Opportunity spaces/ Structure (POS), Eishinger menyebutkan POS (Opp, 2009) adalah ruang multidimensi yang tidak hanya dapat memberi kesempatan bagi tumbuhnya gerakan sosial, tetapi juga dapat menghambat berkembangnya gerakan sosial dalam sebuah kurun waktu (Kriesi, 2004; Opp, 2009). Kondisi terakhir terjadi 
manakalah political structure bersifat represif. Namun secara umum dapat disimpulkan bahwa, hambatan dan suatu kesempatan bagi suatu gerakan sosial dapat dipilah menjadi dua yaitu: Pola tertutup yang menjadi hambatan bagi tumbuh kembang gerakan sosial dan pola terbuka yang memberi ruang luas dan lebih terbuka bagi tumbuh kembang sebuah gerakan sosial. Unsur kedua, Resource mobilization theory, disinilah gerakan sosial diaktualkan. Ketidakpuasan terhadap situasi sosial budaya yang ada tidak berarti apa-apa tanpa adanya sekelompok orang (institusi sosial) yang berupaya melakukan kegiatan mobilisasi yang tentu saja bersandar pada sumber daya yang ada. Unsur ketiga, Social Framing, merupakan kerangka interpretasi yang memungkinan orang untuk menempatkan, memahami, mengidentifikasi dan menamai peristiwa-peristiwa yang terjadi dalam kehidupan sosial yang terjadi di sekitar mereka maupun dunia secara keseluruhan (Snow, 2004). Frame berperan membantu orang menyarikan peristiwa dan atau kejadian menjadi pengalaman bermakna, kemudian mengorganisasi pengalaman tersebut dan memberi panduan untuk bertindak.

\section{Metode Penelitian}

Penelitian ini menggukan metode kualitatif. Pengumpulan data dilakukan melalui teknik studi literatur dan wawancara. Pengumpulan data melalui teknik wawancara melibatkan tokoh-tokoh Muhammadiyah yang memahami dan mengalami di Sulawesi Tenggara. Analisis data dilakukan secara mendalam mengacu pada kaidah Miles dan Huberman, serta kerangka konseptual gerakan sosial sebagaimana yang diuraikan pada latar belakang di atas menjadi acuan dalam pengumpulan dan analisis data penelitian ini.

\section{Hasil}

Sejak mula keberadaannya organ ini telah mendirikan sejumlah lembaga pendidikan dengan tujuan untuk mencerahkan akal budi masyarakat Indonesia (Suryana, 2009). Peacock mencatat bahwa pada tahun 1939 Muhammadiyah sudah mendirikan 1.744 sekolah dari segala tingkatan (Peacock,1968), kini jumlah tersebut terus meningkat. Dalam perkembangan lebih lanjut gerak sosial Muhammadiyah dalam bidang pendidikan, tidak saja dalam ranah pendidikan dasar dan menengah tetapi juga merambah ke dunia pendidikan tinggi. Kepedulian Muhammadiyah terhadap dunia pendidikan tidak dapat disanksikan. Fakta empiris menunjukkan bahwa dimanapun papan Muhammadiyah berdiri, disitu terdapat lembaga pendidikannya (Ali, 2016). Dalam usianya yang lebih seabad, Muhammadiyah dengan segala keterbatasannya berhasil mewujudkan ribuan lembaga pendidikan, mulai dari tingkat PAUD hingga Pendidikan Tinggi. Dalam dunia pendidikan tinggi, Muhammadiyah kini memiliki atau mengelolah 164 Perguruan Tinggi. Jumlah tersebut diperkirakan akan terus bertambah, seiring dengan tuntutan dan harapan masyarakat terhadap Muhammadiyah (http://suaramuhammadiyah.id/2018/11/13).

Sebagaimana di daerah lainnya, komunitas Muhammadiyah di Sultra sejak awal perkenalannya dengan wilayah ini yaitu antara tahun 1929-1930, menandai keberadaannya dengan mendirikan lembaga pendidikan. Lembaga pendidikan pertama Muhammadiyah di Sultra adalah setingkat sekolah menengah yang didirikan pada tahun 1932 di Muna (Depdikbud, 1982). Pada tahun 1952 Muhammadiyah membangun sekolah guru agama (PGAP) di Buton dan mendirikan Madrasah Ibtidaiyah pada tahun 1964 di Wolo Kolaka dan di Tojabi 
Kolaka Utara serta Kendari 1968 (Alifuddin, 2019). Giat Muhammadiyah membangun bangsa melalui pendirian lembaga pendidikan terus berlanjut, meski demikian giat pendirian lembaga pendidikan oleh Muhammadiyah antara tahun 1930 hingga tahun 2000 baru sebatas lembaga pendidikan tingkat dasar menengah, TK, SD/Madrasah Ibtidaiyah, SMP/Madrasah Tsanawiyah, Sekolah Guru (PGA dan SPG) serta SMA.

Dengan demikian, dalam rentan waktu tersebut Muhammadiyah belum dapat membangun dan atau menyediakan jasa layanan pendidikan tinggi kepada masyarakat Sultra. Pertanyaannya kemudian adalah mengapa dalam limit waktu terbilang panjang, Muhammadiyah Sultra belum dapat mewujudkan jasa layanan pendidikan tinggi, kapan Muhammadiyah memulainya dan bagaimana hal tersebut diwujudkan oleh komunitas Muhammadiyah serta bagaimana gerak pertumbuhannya. Deskripsi kritis analitik atas sejumlah pertanyaan tersebut akan dibentangkan di bawah ini.

\subsection{Sketsa Sejarah dan Dinamika Pertumbuhan Perguruan Tinggi Muhammadiyah (PTM) di Sulawesi Tenggara.}

Meski jejak keberadaan Muhammadiyah di wilayah ini telah eksis, 15 tahun sebelum Indonesia merdeka, namun organisasi ini baru mampu memberi layanan pendidikan tinggi kepada masyarakat Sultra pada tahun 2000 atau sekitar 70 tahun setelah masa awal pembentukannya. Yaitu dengan berdirinya secara resmi Universitas Muhammadiyah Buton dan disusul 1 tahun kemudian (2001) dengan berdirinya Universitas Muhammadiyah Kendari (UM Kendari). Lamanya rentan waktu keberhasilan Muhammadiyah dalam mewujudkan pendirian lembaga pendidikan tinggi di Sultra bukan tanpa alasan. Selain faktor keterbatasan sumberdaya, juga tidak dapat dilepaskan dengan gaya tarik politik yang mengitari sistem sosial dimana Muhammadiyah bereksistensi.

Secara historis pendirian lembaga pendidikan Muhammadiyah di Sultra, dalam faktanya lebih banyak didominasi oleh jalan berliku dan penuh halang rintang, yang umumnya lebih berdimensi politik. Realitas halang rintang politik yang dialami oleh Muhammadiyah sangat boleh jadi karena posisi organ ini sebagai gerakan sosial keagamaan berparadigma amar makruf nahi mungkar. Yaitu kerangka paradigmatis dengan sensitifitas tinggi terhadap situasi sosial tetapi sekaligus kritis, baik terhadap otoritas struktural maupun kultural. Eksistensi tersebut sedikit banyaknya berimplikasi bagi gerak pertumbuhan dan perkembangan Muhammadiyah di ruang publik, baik sebelum masa kemerdekaan maupun setelah kemerdekaan.

Pada tahun tahun 1932 Muhammadiyah telah membangun sekolah di Muna yang tersebar di dua tempat yaitu di Raha dan Mabolu. Lembaga tersebut didirikan guna memfasilitasi kelompok bumi putra setempat yang hanya bisa mendapat layanan pendidikan jika berpindah aqidah. Atau dengan kata lain dua lembaga Muhammadiyah didirikan sebagai anti tesa dari lembaga pendidikan Kristen yang didukung oleh pemerintah Hindia Belanda. Akibatnya lembaga tersebut dihalangi hingga diberhentikan operasionalnya oleh Belanda (Depdikbud,1978) Demikian pula dengan sejarah pendirian lembaga pendidikan Muhammadiyah di Ponre Kolaka pada tahun 1989. Lembaga tersebut baru terwujud ketika penggagasnya dapat bersikap lunak dan akomodatif dengan pemegang otoritas politik mayoritas masa Orde Baru (wawancara). Aldjufri menyebutkan tampaknya ruang gerak 
Muhammadiyah Sultra, baik pada masa Orde Lama maupun pada masa Orde Baru, berada pada situasi kurang beruntung. Implikasinya dalam waktu yang lama, akselarasi dari langkah Muhammadiyah menjadi terhambat sehingga berimplikasi signifikan bagi tumbuh kembang organisasi dan atau gerak langkah dari organ ini terkesan kurang berjalan mulus (wawancara).

Jalan terjal penuh liku dan rintangan yang dihadapi oleh elemen Muhammadiyah ketika berupaya membangun lembaga pendidikan sebagaimana sampel dikemukakan, potretnya juga mengejawantah ketika Muhammadiyah berniat membangun pendidikan tinggi. Namun demikian, meski menghadapi beragam tantangan, mulai dari masa penjajahan Hindia Belanda, Orde Lama dan Orde Baru atau bahkan nuansanya kembali muncul setelah 10 (sepuluh) tahun masa reformasi (masa periode kedua SBY dan paruh pertama masa Jokowi), namun komunitas Muhammadiyah di wilayah ini tidak kenal menyerah, bergerak dan terus bekerja dalam giat dakwah pendidikan di Sultra.

Pada awal reformasi, Muhammadiyah menemukan momentum tepat untuk bereksperimen membangun perguruan tinggi dalam rangka memenuhi asa dan cita-cita yang sekian lama hanya tertuang dalam konsep. Keterbukaan politik masa reformasi ditindaklanjuti oleh elemen Muhammadiyah di wilayah ini secara elegan. Tidak ingin terjebak dalam ruang eforia politik, Muhammadiyah menginisiasi langkah strategis dan terukur dengan membangun desain pendirian Perguruan Tinggi Muhammadiyah (PTM). Roda inisiasi pendirian PTM pada masa awal reformasi digerakkan elemen Muhammadiyah yang bereksistensi di Buton dan Kendari. Sebagai tindak lanjut dari upaya mengisi ruang dan kesempatan yang disajikan oleh keterbukaan sistem politik masa reformasi, maka elemen Muhammadiyah di kedua tempat bergerak simultan. Dengan dikomandani oleh Subair di Buton dan Abdullah Alhadza di Kendari, warga Muhammadiyah di kedua tempat bekerja keras merealisasikan asa membangun PTM. Hasilnya pada tahun 2000 dan 2001 dua perguruan tinggi Muhammadiyah dapat terbangun di Sultra (Alifuddin, 2021).

Tiga belas belas tahun setelah pendirian dua Universitas Muhammadiyah sebagaimana disebutkan, sejumlah kader persyarikatan yang bergiat di sejumlah daerah berpikir mendirikan PTM pada tempat mereka berpijak. Muhammadiyah melintas batas, demikian jargon yang tertanam dan menggeliat dalam gugus pikir elemen Muhammadiyah. Oleh karena itu, jika masa-masa sebelumnya Muhammadiyah banyak diidentikkan dengan organisasi perkotaan (urban), maka pandangan tersebut saatnya direvisi, karena indikasi desa, pedalaman bahkan pesisir kini menjadi lahan subur tumbuh kembang Muhammadiyah (Barbasy, 2020).

Adalah Muhammadiyah Wakatobi yang secara eksistensial menempati pulaupulau kecil berkarang dan berada pada alur persimpangan laut Banda dengan ombaknya yang terkenal ganas, merupakan wujud dari fenomena komunitas Muhammadiyah pesisir progresif. Sekalipun baru terbentuk pada tahun 2010, elemen Muhammadiyah di wilayah ini mengukir rencana besar untuk mendirikan Perguruan Tinggi sebagaiaman daerah-daerah lainnya. Niat luhur tersebut selain didorong oleh keinginan meluaskan sayap pengaruh Muhammadiyah melalui Amal Usaha di bidang pendidikan tinggi, juga karena dalam kenyataannya banyaknya alumni SMA dan SMK tidak dapat melanjutkan studinya ke jenjang pendidikan tinggi dengan sebab tidak tertampung di PTN dan atau kendala belum 
adanya lembaga pendidikan tinggi di daerah tempat mereka berdomisili. Menyadari kondisi tersebut, kader-kader Muhammadiyah Wakatobi memberanikan diri untuk tampil mendirikan perguruan tinggi di wilayah tersebut (Arusani, wawancara).

Terhitung sejak tahun 2013 komunitas Muhammadiyah di Wakatobi dengan segala keterbatasannya mengusahakan berdirinya PTM di kepuluan tersebut. Niat dan usaha Pimpinan Daerah Muhammadiyah Wakatobi menyediakan layanan pendidikan tinggi bagi anak-anak kepuluan Tukang Besi bukanlah hal mudah, mengingat eksistensi kepengurusan Muhammadiyah di daerah tersebut terbilang baru, karena merupakan wilayah hasil pemekaran dari Kabupaten Buton. Selain itu, Wakatobi tergolong daerah yang sangat kecil dimana luas daerahnya terdiri dari $97 \%$ lautan dan hanya $3 \%$ daratan dengan sumber daya manusia atau Muhammadiyah-nya, baik dari sisi kuantitas maupun kualitas terbilang sangat terbatas. Realitas tersebut tentu menjadi tantangan sekaligus sebagai hambatan signifikan bagi upaya realisasi Perguruan Tinggi Muhammadiyah (PTM). Faktor lain adalah problem "politik", masa tahun 2013 hingga 2019 pemangku kebijakan politik bidang pendidikan tinggi, oleh sebagian anggota Muhammadiyah diasumsikan terkadang kurang bijak dalam merespon usulan Muhammadiyah (Mustam,wawancara). Seluruh tantangan tersebut menjadi varible penghambat dan menguras banyak energi dari elemen Muhammadiyah.

Pergantian pemangku kebijakan politik pendidikan pasca pemilihan Presisden masa periode kedua Jokowi, plus digitalisasi sistem pengusulan berkas pendirian perguruan tinggi membuka kesempatan dan asa baru bagi realisasi PTM di Wakatobi. Dengan dukungan penuh PP. Muhammadiyah, Wilayah dan assesment aspek teknis dari UMK dan UMB, maka pada tahun 2019 usulan pendirian PTM di Wakatobi mendapat persetujuan dari LLDIKTI IX. Lebih lanjut 7 Oktober 2020 setelah sebelumnya melalui proses assemen dan visitasi lapangan, Kementerian Pendidikan dan Kemudian mengeluarkan SK bernomor 942/M/2020 tentang Izin Pendirian Institut Teknologi Bisnis Muhammadiyah (ITB-M) Wakatobi. Dengan keluarnya surat tersebut, Perguruan Tinggi Muhammadiyah Wakatobi secara resmi beroperasi dan memberi layanan jasa pendidikan tinggi kepada masyarakat setempat.

Terpicu dengan keberhasilan Wakotobi mewujudkan PTM, sejumlah Pimpinan Daerah Muhammadiyah (PD) menginisiasi pendirian PTM di antaranya, Kolaka (2015),Kolaka Utara (2021), Muna Barat (2021) dan Muna (2021). Geliat untuk mendirikan perguruan tinggi tidak hanya terjadi di lingkungan Muhammadiyah, tetapi juga di kalangan ibu-ibu Aisyiyah yang merupakan organ otonom dari Muhammadiyah. Komunitas perempuan yang berafilisasi di Muhammadiyah tersebut pada akhir 2019 menginisasi pendirian Istititut Sains Teknologi dan IImu Kesehatan (ISTEK) Kendari. Usaha dan kerja keras Aisyiyah selama kurang lebih dua tahun kemudian berbuah manis. Didahului dengan persetujuan LLDIKTI dan dilanjutkan dengan assesment lapangan pada 14 Desember 2021, perguruan tinggi ISTEK kemudian mendapat persetujuan izin operasional dari Kemendikbudristek pada tangga 27 Januari 2022. Izin tersebut tertuang dalam SK bernomor 42/E/0/2022.

Sebulan setelah ISTEK berdiri disusul oleh ITB-M Kolaka, dan sangat mungkin pada tahun 2022 ini PTM di Kolaka Utara dan di Muna Barat akan mendapatkan izin operasional dari Kemendikbudristek pada tangga 18 Februari 
2022. Izin tersebut tertuang dalam SK bernomor $83 / E / 0 / 2022$, dan berselang 3 hari setelahnya yaitu tanggal 21 Februari 2022, Kemendikbudristek mengeluarkan SK bernomor 107/E/2022 tentang izin pendirian Institut Teknologi dan Sains (INTENS) Kolaka Utara. Dengan demikian per 21 Februari secara kuantitatif Muhammadiyah Sultra telah memiliki enam perguruan tinggi. Jumlah tersebut masih sangat mungkin bertambah, mengingat terdapat satu PTM yang perizinannya sedang dalam proses yaitu ITB-M Muna Barat.

\subsection{Tumbuh Kembang PTM di Sulawesi Tenggara}

Semangat beramal yang berbasis pada jargon fastabiqul khairat (berlomba dalam mewujudkan kebaikan) dalam faktanya menyatu padu dalam visi anggota dan khususnya para pimpinan Muhammadiyah. Karena itupulah dorongan untuk menumbuhkan kembangkan amal usaha persyarikatan tetap berkelanjutan di lingkungan Muhammadiyah. Kehadiran dua PTM pada awal tahun 2000-an, ditambah dengan terwujudnya PTM di Pusat Segi Tiga Karang Dunia Wakatobi pada tahun 2020, mendorong sejumlah Pimpinan Daerah Muhammadiyah (PDM), untuk berbuat plus membangun infrastruktur akal budi di tempat/daerah mereka masing-masing.

Niat dan Giat pendirian PTM baru di lingkup Sultra, selain karena kebutuhan masing-masing daerah juga dipicu oleh keberhasilan PDM Wakatobi membangun perguruan tinggi di pulau karang tersebut. Berawal dari moment tersebut selain PDM Kolaka yang telah lebih awal mendapatkan persetujuan LLDIKTI Wilayah IV, maka sejumlah Pimpinan Daerah terdorong untuk berfastaqul khairat mendirikan PTM. Sebelum tiga daerah lainnya yaitu, Kolaka Utara, Muna dan Muna Barat, Pimpinan Wilayah Aisyiyah pada akhir 2019 menginisiasi lahirnya Institut Sains dan Teknologi Kesehatan (ISTEK) yang bertempat di Kota Kendari. Progres pendirian ISTEK Aisyiyah terbilang cepat bila dibanding dengan Kolaka dan Wakatobi, mengingat usulan tersebut mulai diajukan pada akhir 2020 dan mendapat persetujuan LLDIKTI pada Maret 2020 dan pada akhir atau tanggal Desember 2021 assesment dan visitasi lapangan telah selesai dilakukan oleh Kementerian Pendidikan Nasional pada tanggal 14 Desember 2021. Dan selanjutnya mendapat izin operasional pada tanggal 27 Januari 2020 (Marlina, wawancara). Demikianpula dengan Kolaka Utara dan Muna Barat.

Sungguhpun tumbuh kembang amal usaha Muhammadiyah bidang pendidikan tinggi di Sultra terbilang lamban bila dibandingkan dengan wilayah Muhammadiyah lainnya seperti Sulawesi Selatan, namun gerak ke-arah progresivitas mulai ditunjukkan khususnya dalam 5 (lima) tahun terakhir. Deskripsi tentang langka-langkah sejumlah Pimpinan Daerah Muhammadiyah menginisiasi lahirnya PTM merupakan penanda eksplisit bahwa eksponen Muhammadiyah di wilayah ini masih tetap "siuman". Bahkan fenomena kebangkitannya perlahan tapi pasti mulai terlihat. Realitas tersebut menunjukkan pada sustainabilitas gerakan pendidikan Muhammadiyah di Sultra. Melalui langkah yang sekarang telah diukir oleh komunitas Muhammadiyah di berbagai daerah, maka sangat memungkinkan untuk masa 2 dua atau tiga tahun mendatang Muhammadiyah di wilayah ini secara kuantitatif berpotensi memiliki 8 hingga 10 Perguruan Tinggi. Dengan jumlah tersebut, boleh jadi hingga tahun 2025 Muhammadiyah akan tetap menjadi 
ormas Islam terdepan di wilayah ini dalam bidang tatakelola kelembagaan pendidikan tinggi swasta baik secara kuantitatif maupun kualitatif.

\subsection{Perkembangan dan Pertumbuhan Perguruan Tinggi Muhammadiyah di Sulawesi Tenggara}

Meski terkesan lamban, namun hingga pertengahan Februari 2022 elemen Muhammadiyah Sultra kini memiliki lima perguran tinggi, dan berpotensi menjadi 7 jika INTENS Kolaka Utara dan ITBM Muna Barat mendapat izin operasional. Capaian ini bila dibandingkan dengan organ sejenis yang bereksitensi di Sultra dapat dikatakan sangat maju. Fakta menarik lainnya dua Perguruan Tinggi Muhammadiyah yaitu UM Buton dan UMK (Kendari) merupakan dua PTS papan atas di Jazirah Sulawesi Tenggara. Hal ini setidaknya berdasarkan liris Unirank dimana kedua perguruan tinggi tersebut berada pada urutan ketiga dan keempat dari sepuluh perguruan tinggi di Sulawesi Tenggara (Kendari info, 2022). Kedua PTM tersebut kini menjadi pilihan utama bagi lulusan SLTA di Sultra. Keduanya merupakan tempat dan tujuan sebagian masyarakat atau banyak orang menggantungkan harapan masa depan anaknya untuk dididik menjadi sarjana. Menariknya sekalipun kedua universitas tersebut tidaklah berada pada lokasi atau wilayah tujuan pendidikan seperti Kota Makassar dan Jawa, namun input atau sumber mahasiswanya tidak hanya datang dari wilayah Sultra, tetapi juga dari provinsi lainnya seperti Papua, Maluku, Maluku Utara, Sulawesi-Tengah bahkan dari wilayah Nusa Tenggara Timur (Arsip UMB dan UMK, 2021).

Perkembangan dua perguruan tinggi Muhammadiyah di Sultra dapat dikatakan cukup maju. Hal ini setidaknya dapat dilihat pada dua indikator yaitu dari sisi penyelenggaraan akademik dan akselarasi sarana penunjang pembelajaran. Dari sisi prestasi akademik kedua universitas secara institusional telah terakreditasi, demikian pula dengan seluruh program studi seluruhnya terakreditasi B kecuali program studi yang baru dibuka. UM Kendari memiliki akreditasi institusi B dan terdapat dua prodi terakreditasi A, demikian pula di UM Buton semua prodinya telah memiliki peringkat akreditasi. Karena itulah dua institusi tersebut menjadi PTS favorit bagi lulusan SLTA di Sulawesi Tenggara. Dengan status akreditasi institusi menunjukkan bahwa PTM dapat bersaing dengan sejumlah perguruan tinngi negeri yang juga akreditasi institusinya B seperti UHO dan USN. Realitas ini dapat dikatakan sebagai penanda eksplisit, jika kedua PTM memiliki manajemen tatakelola sistem akademik yang baik.

Dari sisi sarana penunjang pembelajaran, kedua PTM memiliki ruang pembelajaran dan sarana perkuliahan lainnya yang representatif bila dibanding dengan sejumlah PTS lainnya di Sulawesi Tenggara. Kedua PTM memiliki peluang untuk semakin memperbesar kampus masing-masing karena memiliki modal lahan bagi pengembangan kampus yang cukup besar, UM Kendari memiliki lahan pengembangan seluas kurang lebih 20 hektar, demikian pula UM Buton. Kemampuan dua PTM tersebut membangun infrastruktur yang megah dan besar, secara tersirat menunjukkan pada fakta bila perkembangan kedua PTM tersebut cukup sehat dari sisi tatakelola finansial/sumber daya keuangan (ibid). 


\section{Pembahasan}

\subsection{Perkembangan PTM di Sulawesi Tenggara dalam Bingkai Gaya Tarik Politik Pra dan Pasca Reformasi}

Sebagai institusi sosial budaya keagamaan, peran pemberdayaan Muhammadiyah terhadap masyarakat Indoensia amat sangat besar, menyejarah dan mengejawantah di bumi Nusantara sebelum dan setelah Indonesia merdeka. Melihat bentuk dan perannya, Muhammadiyah merupakan bagian integral dari definisi gerakan sosal baru (new social movement), karena faktanya komunitas Muhammadiyah dalam menjalankan aktivitas atau tindakan sosial dijalankan secara kolektif dalam rangka mencapai keinginan yang dicita-citakan bersama (Sills,nd). Meskipun demikian tindakan sosial Muhammadiyah sangatlah berbeda dengan kebanyakan LSM, gerak sosial Muhammadiyah merupakan panggilan moral keagamaan yang berbasis pada konsep teologi al-ma'un sebagaimana disebutkan dalam Quran. Arfandi menyebutkan komitmen Muhammadiyah sebagai gerakan sosial dalam mendorong kesejahteraan tidak kontraproduktif dengan tujuan lahirnya negara maupun welfare state. Peran ini sama sekali berbeda dengan konsepsi yang diterapkan oleh beberapa kelompok Islamis, baik di dalam maupun di luar negeri yang berkecenderungan memanfaatkan gerakan sosial filantropi untuk menggerogoti legitimasi negara (Arfandi, 2016)

Sungguhpun fakta menunjukan bahwa gerak sosial Muhammadiyah selalu memberdayakan plus memperkuat sumber daya milik Negara, baik di saat krisis maupun ketika masa perekonomian membaik. Namun sebagai bagian dari komunitas sosial, Muhammadiyah acapkali berhadapan dengan realitas gaya tarik menarik politik oknum yang memanfaatkan kekuasaan untuk mempersempit ruang gerakan sosial Muhammadiyah membangun keadaban. Dalam konteks itulah, penting memahami peran sosial Muhammadiyah sebagai bagian dari bangsa dalam perspektif political opportunity space/structure (POS). POS merupakan variable yang memberi muatan penjelasan tentang hubungan antar perubahan dalam sebuah struktur dan sistem politik dengan upaya mobilisasi suatu gerakan (Benfoord, 2000). Atau sebagaimana kata Eishinger POS adalah ruang multidimensi yang tidak hanya dapat memberi kesempatan bagi tumbuhnya gerakan sosial, tetapi juga dapat menghambat berkembangnya gerakan sosial dalam sebuah kurun waktu (Opp, 2009; Kriesi, 2004)

Dalam sebuah ruang politik terbuka dan berbasis pada demokratisasi yang sehat, lazimnya akan memberi ruang, peluang dan kesempatan bagi tumbuh kembang suatu gerakan sosial secara fair. Sebaliknya, pada suatu sistem tertutup, represif dan atau menguatnya basis politik sektarianisme (identitas) dapat menyebabkan kelompok-kelompok sosial tertentu menjadi termajinalkan atau mendapatkan perlakuan kurang adil. Oleh karena itu, fakta tentang adanya hubungan antara sebuah struktur dan sistem politik dengan gerak maju organ sosial menjadikan tumbuh kembang sebuah organisasi sosial selalu berada dalam situasi fluktuatif. Kondisi dan realitas tersebut juga dialami oleh organisasi sekelas Muhammadiyah baik pada masa kolonialisme, Orde Lama, Orde Baru hingga masa reformasi.

Pasca 1945 hingga 1965, akibat dari adanya relasi kultural antara Muhammadiyah dengan MASYUMI ditambah dengan kebijakan persyarikatan menolak dan menetang NASAKOM mengakibatkan terjadinya jarak antara 
Muhammadiyah dengan pemerintahan Orde Lama. Dalam kondisi tersebut sejumlah tokoh Muhammadiyah yang hidup di era Orde Lama kemudian menjadi tahanan politik. Kemesraan yang ditunjukkan oleh Soekarno terhadap PKI, memaksa sejumlah elemen yang berakar pada kultur Muhammadiyah yang kuat memilih berada pada garda terdepan menentang kebijakan-kebijakan Soekarno. Realitas tersebut dalam faktanya memiliki efek signfikan bagi perkembangan persyarikatan Muhammadiyah.

Pada masa Orde Baru, angin segar yang dirasakan umat Islam (termasuk di dalamnya Muhammadiyah) hanya berlangsung pada paruh paling awal dari Orde Baru. Politik represif Orde Baru dibawa kendali Soeharto menjadikan sebagian besar umat Islam meradang. Aldjufri sebagai Pimpinan Wilayah Muhammadiyah Sultra pada waktu itu merasakan betapa tekanan terhadap organ sosial keagamaan telah menyebabkan kekutan sosial umat Islam terkoyak sehingga tidak dapat mengembangkan kreatifitasnya di ruang publik, karena sifat curiga pemerintah yang sangat tinggi. Dalam konteks Muhammadiyah Sultra tekanantekanan politik berupa pembatasan ruang gerak dalam rangka membangun peradaban seperti berkegiatan dan membangun amal usaha mendapat pengawasan ketat, bahkan terkadang dicurigai (Aldjufri; wawancara). Realitas tersebut faktanya tersaji pada pengalaman komunitas Muhammadiyah Kolaka ketika berupaya membangun pesantren Muhammadiyah di Ponre. Pun dengan kejadian di sejumlah daerah seperti Buton, warga dan pengurus amal usaha Muhammadiyah di Buton oleh oknum militer di bawa Orde Baru bersikap represif terhadap sejumlah anggota Muhammadiyah yang menolak bergabung dengan kekuatan politik Golongan Karya (GOLKAR) sebagai partai pemerintah (Nuki Basir, wawancara).

Ruang segar dan memicu kreatifitas untuk semakin maju bagi eksistensi Muhammadiyah Sultra, ditemukan secara meyakinkan pada 10 (sepuluh) tahun pertama masa reformasi. Masa awal reformasi merupakan momentum awal dari gerak progresif Muhammadiyah di Sultra. Hal tersebut setidaknya ditandai dengan berdirinya dua PTM yaitu Universitas Muhammadiya Buton (UM Buton) dan Universitas Muhammadiyah Kendari (UMK) masing-masing pada tahun 2000 dan 2001. Dalam konteks ruang keterbukaan yang diberi oleh reformasi terhadap kecenderungan gerak progresiv Muhammadiyah Sultra, sesungguhnya tidak dapat dilepaskan dengan andil sejumlah tokoh Muhammadiyah pada gerakan reformasi. Pesohor reformasi masa awal adalah Muhammad Amin Rais, yang pada masa itu menjabat sebagai Ketua Umum PP. Muhammadiyah. Sebagai penggerak reformasi politik 1998, pengaruh Amin pada masa awal reformasi sangat signifikan. Realitas tersebut menjadikan gerak sosial Muhammadiyah dalam upayanya membangun keadaban di bidang pendidikan menjadi lebih leluasa, dan atau lebih mulus dari sebelumnya.

Fakta keterbukaan politik pada tahun 1998, menjadi jalan mulus bagi masyarakat untuk berekspresi pada masa-masa awal reformasi. Ruang dan kesempatan berekspresi sebagai insentif reformasi, direspon oleh komunitas Muhammadiyah secara elegan. Tidak ingin terlena dalam arus eforia reformasi, komunitas Muhammadiyah Sultra mengayuh langkah, membangun asa melalui tindakan kreatif produktif sekaligus bermanfaat bagi masyarakat. Yaitu dengan menginisiasi pendirian Perguruan Tinggi Muhammadiyah (PTM). Atas berkat dari Allah, usaha keras nan kreatif yang ditunjukkan oleh elemen Muhammadiyah 
dalam rangka mewujudkan jasa layanan tinggi kepada masyarakat dikabulkan.. Terhitung dua tahun dari titik awal masa reformasi, Muhammadiyah Sulawesi Tenggara dapat mewujudkan pendirian Universitas Muhammadiya Buton (UM Buton) dan Universitas Muhammadiyah Kendari (UMK) masing-masing pada tahun 2000 dan 2001.

Capain tersebut dapat dikatakan luar biasa, karena dalam waktu dua tahun setelah puasa panjangnya, dengan usaha keras di tengah keterbatasan sumber daya manusia dan dana, Muhammadiyah dapat mewujudkan monumen akal budi, yiatu UMK dan UMB. Sebagai insentif roformasi, dua universitas tersebut oleh Muhammadiyah didedikasikan untuk membangun dan memberdayakan sumber daya manusia Indonesia secara umum dan secara khusus bagi anak-anak Sulawesi Tenggara.

Setelah mendirikan dua perguruan tinggi sebagai dimaksud di atas, Muhammadiyah terus melakukan akselerasi, khususnya untuk meningkatkan kualitas dari dua lembaga yang telah dibangunnya plus menambah kuantitas PTM yang dimilikinya. Namun demikian perkembangan arus politik pasca masa awal reformasi, serta dinamika politik bargaining menjadikan suasana jagad politik Indonesia tercebur dalam warna pekat sektarianisme. Politik bargaining bagi-bagi "jabatan" yang terjadi pada masa periode kedua SBY dan masa periode pertama Jokowi, menjadikan alam kementerian dan lembaga negara, bagai dikuasai oleh "partai" dan atau organisasi sosial tertentu atas nama negara. Realitas ini, sekalipun tidak serepresif masa Orde Baru, dalam skala tertentu berfungsi efektif menghalangi elemen sosial yang tidak seafiliasi dengan pemegang kendali kebijakan politik di kementerian dan lembaga untuk dapat mengembangkan dan melebarkan sayap baktinya kepada negara. Hal ini setidaknya dialami oleh elemen Muhammadiyah Sulawesi Tenggara.

Sainudin Ketua BPH UMK (Kendari) periode 2016-2020 melihat fenomena tersebut dengan sangat jelas, ketika mencoba membangun dan menambah beberapa prodi di UM Kendari. Kesan dipersulit dengan alasan atau indikasi yang tidak jelas dialami oleh UM Kendari sehingga selama masa tersebut upaya untuk menambah 2 (dua) prodi tidak kunjung mendapat izin hingga masa periode pertama dari Presiden Jokowi berakhir (Wawancara). Hal yang sama juga diutarakan oleh Subair ketika mengusulkan pendirian Universitas Muhammadiyah Wakatobi, selalu saja ada masalah baru yang harus diselesaikan setiap kali mengajukan revisi berkas (wawancara). Sehingga usaha pendirian Universitas Muhammadiyah Wakatobi yang diinisiasi sejak awal 2013 baru dapat terealisasi pada pertengahan 2020 dengan berubah nama menjadi Institut Tekonologi Bisnis Muhammadiyah Wakatobi.

Berdasarkan uraian di atas ternyata realitas keterbukaan politik masa reformasi hanya dapat diakses dengan baik pada paruh awal masa reformasi, untuk selanjutnya menjadi tertutup oleh kental pekatnya politik sektarianisme di Kementerian Pendidikan dan Ristek Dikti pada masa kedua kepempimpinan Presiden SBY dan paruh lima tahun tahun pertama masa Presiden Jokowi. Keterbukaan akses publik, kembali dinikmati elemen sosial ketika masa periode kedua Presiden Jokowi. Disatukannya kembali sistem tata kelola pendidikan tinggi dan berada satu atap dengan Kementerian Pendidikan di bawah pengendalian Nadim Makarim, membuka asa baru bagi elemen sosial yang berkhidmat di dunia pendidikan, untuk berkompetisi secara sehat membangun bangsa. Nadim 
membuka kesempatan yang sama bagi setiap elemen sosial untuk berkreasi membangun lembaga pendidikan tinggi. Ruang ini kemudian dimanfaatkan secara bijak oleh elemen Muhammadiyah yang tersebar di seluruh Nusantara untuk mewarnai daerahnya masing-masing dengan menghadirkan Pergurun Tinggi Muhammadiyah. Di Sultra persyarikatan Muhammadiyah dalam dua tahun terkahir melahirkan 4 (empat) PTM dan berpotensi menambah satu PTM. Jika tambahan satu PTM tersebut dapat terealisasi maka Muhammadiyah Sultra hingga tahun 2022 akan telah memiliki 7 (tujuh) Perguruan Tinggi.

\subsection{Kehadiran PTM sebagai Wujud Kemampuan Memobilasasi Sumber Daya}

Mendirikan dan membangun perguruan tinggi tidak sesederhana memikirkannya, karena terdapat sejumlah persyaratan yang niscaya disiapkan bagi elemen yang merencanakannya, baik terkait dengan aspek penyedian perangkat keras maupun perangkat lunaknya. Untuk mendirikan sebuah universitas, pengusul setidaknya harus memiliki bukti kepemilikan lahan seluas 20.000 meter persegi untuk sebuah Universitas dan minimal 8.000 meter persegi untuk setingkat institut. Selain itu elemen pengusul harus dapat menyajikan bukti minimal kepemilikian sementara sejumlah fasilitas infrastruktur fisik sepeerti ruang kantor, kelas standar, perpustakaan, labiratorium, dsb. Yang nilainya bila diuangkan mencapai puluhan miliar rupiah. Belum lagi bukti kemampuan dana untuk menunjang jalannya sebuah perguruan tinggi, seperti dana operasional, gaji dosen dan karyawan.

Sejumlah persyaratan terkait sebaimana dideskripsikan, menyajikan fakta bahwa untuk merealisasikan sebuah perguruan tinggi dibutuhkan pembiayaan yang tidak sedikit. Jika keniscayaan tersebut dihubungkan dengan kehadiran 5 (lima) PTM di Sultra dan 2 (dua) lainnya yang bakal menyusul, mengesankan bahwa setidaknya Muhammadiyah di wilayah ini memiliki basis finansial yang "kuat". Asumsi tersebut linear dengan kebutuhan dasar yang harus dimiliki oleh setiap elemen yang berniat mendirikan perguruan tinggi, benarkah demikian ? Tidaklah mudah untuk menjawabnya, karena secara empiris komunitas Muhammadiyah yang bergerak di wilayah ini, selain secara kuantitatif jumlahnya sangat sedikit, para anggota yang berkhidmat di dalamnya secara umum berasal dari kelompok masyarakat menengah ke bawah. Jika kemudian elemen persyarikatan Muhammadiyah semisal di Pulau Wakatobi demikianpula dengan komunitas perempuan Muhammadiyah yaitu Aisyiyah dapat mewujudkan pendirian PTM di tengah keterbatasan sumber daya manusia dan dana, maka pertanyaannya kemudian adalah "daya" apa yang dimiliki Muhammadiyah sehingga dapat mewujudkan infrastruktur akal budi tersebut? Fenomena gerak komunitas Muhammadiyah Sultra mendirikan, membangun layanan pendidikan tinggi di tengah keterbatasan sumber daya manusia dan dana menarik untuk ditelaah dengan menggunakan teori mobilisasi sumber daya. Atau dengan kata lain bagaimana komunitas terkait menata, memanfaatkan sekaligus mendayagunakan sumber daya yang serba terbatas tersebut sehingga berfungsi maksimal.

Opp menyebutkan sumber daya memiliki cakupan luas meliputi manusia, kekuatan finasial, akses terhadap media, dukungan anggota dan simpatisan, demikian pula loyalitas kelompok, penguasan ilmu dan skill, demikian pula dengan ideologi yang dimiliki oleh aktor (Opp, 2009). Edwards dan McCharty (2004) membagi resources ke dalam beberapa tipe. Yaitu: (1). Moral resources, (2) 
Cutural resources, (3). Sosial organization resources, (4). Human resources, dan (5). Material resources. Baik Opp maupun Edwards dan McCharty, sepakat menyatakan bahwa sumber daya tidak bertumpu semata-mata pada kekuatan material, bahkan Edwards dan McCharty menempatkan kekuatan material pada unsur kelima setelah kekutan moral, kultur (budaya) social organization, dan manusia. Tata urut sumber daya sebagaimana disebutkan sungguhpun boleh jadi tidak dimaksudkan oleh Edwards dan McCharty sebagai sesuatu yang bersifat hirakis, namun kekuatan hirarkis sumber daya sebagaimana disebutkan elan vitalnya dapat ditelisik pada sejarah pendirian PTM di Sultra.

Bahwa aspek kekuatan daya moral, budaya dan ikatan sosial dalam sejarah dan eksistensi Muhammadiyah merupakan modal paling fundamental dalam gerak langkah persyarikatan. Moral dan budaya sosial Muhammadiyah diikat oleh suatu diktum nilai Quran, yaitu untuk selalu berada dalam ruang kompetisi guna menciptakan hal-hal baik dan positif (fastabiqul khairat). Untuk mewujudkan hal tersebut Muhammadiyah membudayakan nilai moral filantropi di atas landasan teologi al-ma'un (Fawzan, 2017). Yaitu, konsep keimanan yang menyatakan keridhaan Allah kepada hambanya hanya dapat diperoleh oleh mereka yang mampu memadukan antara ketataan beribadah mahdah (shalat) dengan kepedulian dan atau inisiatif positif untuk memberdayakan sesama manusia. Prinsip teologi al-ma'aun mengejawantah dalam perilaku beramal jariyah. Moral dan budaya sosial beramal jariyah inilah yang berhasil dihidupkan dan dimobilisasi oleh elemen Muhammadiyah sehingga elemen sosial ini mampu mewujudkan monumen akal budi dalam bentuk layanan pendidikan tinggi di beberapa daerah di Sultra. Sebagai kultur identitas kerja untuk membangun dan berlomba dalam kebaikan (fastabiqul khairat) ditunjukkan secara nyata oleh komunitas Muhammadiyah tanpa terikat oleh masa dan tempat (Nasir, 2019). Moral sosial dan budaya fastabiqul khairat berbasis teologi al-ma'un, merupakan instrumen nilai yang dapat menjelasakan mengapa Muhammadiyah dapat menumbuhkan amal usaha, kendatipun para penggeraknya mayoritas berasal dari kelompok sosial ekonomi menengah ke bawah. (Usman, 2019)

Kehadiran sejumlah PTM di ruang publik Sultra merupakan bentuk paling rill dari kepedulian Muhammadiyah untuk mencerdaskan kehidupan bangsa, meski demikian kehadiran sejumlah PTM tersebut tidak muncul secara sim salabim. Bahwa tidak sedikit tantangan dan halang rintang dalam proses mewujudkan PTM di Sultra, adalah sesuatu yang niscaya dipercaya. Dan jika kini institusi PTM yang membersamai publik Sultra tampak terlihat kokoh menelusuri alur zaman, maka dipastikan realitas tersebut memiliki keterkaitan erat dengan etos dan militansi para pendiri dan penggeraknya. Pada gilirannya harus dinyatakan bahwa perwujudan nyata PTM dalam ruang publik Sultra mengkofirmasikan tentang "kemampuan" elemen Muhammadiyah mendayagunakan sumber daya secara efektif.

\subsection{Framing proses}

Berdirinya PTM di sejumlah kabupaten kota dalam lingkup Sultra dua tahun terakhir, merupakan penanda eksplisit dari keseriusan Muhammadiyah menjawab serta memenuhi asa sebagian masyarakat di wilayah ini untuk dapat melanjutkan pendidikan generasi pelanjut mereka, tanpa harus meninggalkan kampung halaman. Semangat membangun dan menginisasi lembaga pendidikan oleh elemen persyarikatan sebagaimana disebutkan tidaklah berada dalam ruang 
hampa budaya, tetapi diikat oleh komitmen kuat untuk memajukan lembaga yang telah ada melalui beragam pendekatan dalam rangka merawat kepercayaan masyarakat.

Sebagai "produk" dari layanan jasa pendidikan, PTM niscaya hidup dan atau dihidupkan dalam hati dan pikiran masyarakat. Hanya dengan cara demikian, maka lembaga pendidikan swasta seperti PTM dapat terus mengarungi dan mempertahankan eksistensinya di ruang publik. Oleh karena itu, giat sosialisasi, promosi dan pemasaran terhadap prodak dari jasa layanan pendidikan yang ditawarkan menjadi giat tak terhindarkan oleh pengelola PTM. Kemampun sosialisasi dan promosi dengan cara elegan, dalam perspektif gerakan sosial di sebut "framing". Yaitu aktivitas yang merujuk pada fenomena aktiv dan berproses dengan melibatkan agen dalam membagun realitas. Goofman menyebutkan framing adalah skema dari intrepretasi yang memungkinkan individu, dapat atau mampu memetakan, memahami dan mengindentifikasi serta memberi label atas setiap peristiwa atau kejadian dalam ruang sosial budaya dan atau dalam ranah kehidupan dunia secara umum (Benfoord, 2000; Snow;2004).

Baik 3 (tiga) PTM yang telah eksis di ruang publik maupun yang baru berdiri di tahun 2022, kesemuanya mengukuhkan eksistensinya melalui proses sosialisasi dan promosi dengan jalan membangun citra positif keberadaannya di runag publik. Tidak dapat dipungkiri, bahwa eksistensi PTM di Sultra dapat atau mampu berkelanjutan seperti tampak sekarang, selain ditunjang oleh kemampuan elemen Muhammadiyah memobilisasi sumber daya serta adanya daya dukung situasi sosial politik yang kondusif, juga terkait erat dengan upaya kuat (kemampuan) elemen persyarikatan mempromosikan sekaligus membingkai kemasan PTM sebagai sesuatu yang berdaya tarik, plus bernilai manfaat bagi masyarakat di wilayah ini.

Modal jejaring Muhammadiyah dalam dunia pendidikan yang kini telah masuk hingga ke benua Australia menjadi daya tawar yang penuh arti bagi pengambil kebijkan untuk beringan tangan mengizinkan pendirian PTM baru di Sultra. Pada sisi lain, relasi dan jejaring luas yang dimiliki Muhammadiyah, memantik daya pikat para penggiat pendidikan dan masyarakat untuk mengambil bagian dengan jalan memberi dukungan terhadap pengembangan dan inisiasi pendirian lembaga pendidikan tinggi Muhammadiyah. Kekuatan jaringan PTM yang berjumlah 164 menjadi "jualan" PTM di Sultra. Framing keunggulan kompetitif PTM bila dibanding dengan PTS lainnya di Sultra, bukan sesuatu yang mengada-ngada. Bagi pembaca cerdas, tentu saja dengan mengetahui jumlah PTM sebanyak itu, menjadi garansi tersendiri bagi para calon mahasiswa baru yang berniat memanfaatkan jasa layanan PTM. Secara logis, tingkat resiko berkuliah pada PTM dengan jejaring luas akan sangat rendah bila dibanding dengan perguran tinggi lainnya yang tidak berjejaring. Oleh karena itu, selain menframing keunggulan kompetitifnya dalam bidang akademik, PTM di wilayah ini juga menawarkan jasa layanan pendidikan dengan tingkat resiko yang rendah. Fakta tersebut dapat diolah secara elegan oleh penggiat Muhammadiyah, sehingga menjadikan gugus PTM sebagai pilihan meyakinkan bagi lulusan SLTA di Sultra.

Megejawantahkan citra, kelebihan dan keunggulan kompetitif sebuah lembaga pendidikan tinggi menjadi sesuatu yang tak terelakkan. Mengingat keberlanjutan sebuah perguran tinggi swasta terkait erat dengan tinggi rendahnya keyakinan masyarakat terhadap lembaga tersebut, akan sangat menentukan 
keberlanjutan lembaga tersebut pada masa berikutnya. Dalam konteks latar pemikiran tersebut, maka proses pencitraan oleh sebuah lembaga sebagai upaya kreatif untuk menarik simpatik pengguna jasa dapat dimengerti. Strategi framing dengan memanfaatkan jejaring dan prestasi yang telah dilakukan dalam kerangka membangun inisiatif masyarakat untuk ikut serta berada dalam satu perahu bersama PTM, baik ketika awal mula pendiriannya maupun ketika PTM tersebut telah "mapan" tetap menjadi strategi yang terelakkan oleh penggiat Muhammadiyah. Kehadiran UMK, UMB, ITBM Wakatobi, ISTEK AISYIYAH, dan ITBM Kolaka menurut penulis tidak dapat dilepaskan dari kemampuan penggiat Muhammadiyah dalam mengemas sekaligus mempublish gagasan tersebut ke ruang publik.

Hadirnya ribuan mahasiswa pada tiga PTM yang telah dahulu eksis dan kemudian menjadikan kedua lembaga tersebut dapat tetap survive di tengah arus deras dinamika persaingan ketat antara lembaga, secara konseptual atau merupakan indikator sederhana atas keberhasilan framing yang dilakukan. Benfoord menyebutkan bahwa framing dihadirkan oleh pelaku atau pengelolah gerakan bertujuan agar gagasan atau bahkan ideologi yang diusung oleh sebuah gerakan merebut simpati dan atau memperoleh dukungan publik. Selain dukungan, framing juga menjadikan sebuah gerakan dapat memberi label terhadap pengalaman-pengalaman yang akan dijadikan sebuah guideline dalam bergerak dan bertindak (Benfoord, 2000; Snow, 2004).

\section{Kesimpulan}

Pertumbuhan dan perkembangan PTM di Sultra secara historis tidak dapat dilepaskan dengan dinamika politik kenegaraan yang sedang berkembang. Dari tiga PTM yang kini telah eksis dan disusul oleh kehadiran ISTEK AISYIYAH, ITBM Kolaka seluruhnya terwujud dalam suasana politik yang terbuka dan atau berbasis pada penilian yang fair, jauh dari praktik politik sektarian/partisan. Pertumbuhan dan perkembangan PTM di Sultra, terkait erat dengan kemampuan elemen persyarikatan mengelola setiap kesempatan (momen) sebagai momentum untuk mewujudkan monumen infrastruktur akal budi. Fakta tersebut dapat terjadi karena kekuatan jaringan, sifat kolektif kolegial dan kuatnya etos filantropi warga Muhammadiyah. Modal sosial budaya tersebut dapat dikelola dan dimobilisasi secara elegan sehingga pada gilirannya memberi kekuatan bagi penggiat Muhammadiyah di wilayah ini untuk tidak sekedar mengembangkan PTM yang telah ada tetapi juga membangun PTM baru.

Seluruh kekuatan modal sosial budaya plus jaringan luas, oleh elemen Muhammadiyah tidak dibiarkan membeku tetapi tetapi diaktualkan melalui proses "framing" yang cerdas dan elegan. Melalui sosialisasi, promosi dan pemasaran ide yang faktual memantik banyak pihak untuk terlibat guna maju bersama Muhammadiyah untuk membangun dan mengembangkan PTM di Sultra.

\section{Ucapan Terima Kasih}

Terimakasih yang sedalam-dalamnya kami haturkan kepada Rektor IAIN Kendari, Rektor Universitas Muhammadiyah Buton, Rektor Universitas Muhammadiyah Kendari, Rektor ITBM Wakatobi serta semua tokoh Muhammadiyah Sulawesi Tenggara yang telah berkontribusi besar terhadap pelaksanaan penelitian ini. 


\section{Daftar Pustaka}

Alifuddin, Muhammad. (2021). Muhammadiyah sebagai Gerakan Pendidikan: Sejarah Eksistensi Perguruan Tinggi Muhammadiyah, al-Ta'dib, 14 (1)

Alifuddin Muhammad. (2020). Muhammadiyah's Educational Philantropy Movement in North Kolaka, Shautut Tharbiyah, 26 (1).

Ammar, Fawzan. (2017). Implementasi Filantropi Islam di Indonesia, Jurnal Ekonomi Islam dan Filantropi, 1 (1).

Arfandi, Hafidz. (2016). Motif dan Strategi Gerakan Filantropi Muhammadiyah, Jurnal Muhammadiyah Studies, 1 (1).

Barbasy, Ma'mun Murad. (2020). Geliat Muhammadiyah di Pedesaan, IbTimes.id, diakses, 10-02-2022.

Banakit, Intan Diana. (2020). Internasionalisasi dan Reformasi Perguruan Tinggi: Studi Kasus Pada Lembaga Pendidikan Muhammadiyah, Jurnal Dinamika Manajemen Pendidikan (JDMP), 4 (2).

Benfoord, Robert. (2000). Framing Process and Socila Movement: An Over view and Assesment dalam Annual Reiview of Sociology,

Jannah, Rahmiyani. (2019). Muhammadiyah Dan Inovasi Pendidikan Islam" Jurnal Manajemen Pendidikan dan Keislaman, 8 (1).

Syaifuddin, Muhammad Arif. (2019). Sejarah Sosial Pendidikan Islam Modern Di Muhammadiyah, Tadarus, Jurnal Pendidikan Islam, 8 (1)

Suryana, Cecep. (2009). Kiprah Politik Dan Sejarah Organisasi Muhammadiyah Di Indonesia, Jurnal Ilmu Dakwah, 4 (14).

Kriesi, Hanspeter. (2004). Political Context and Opportunity, dalam Blackwel Companion to Social Movement Massachusets : Balckwell Publishing.

Miles, Matthew B. \&Huberman. (1986). Qualitatif Data Analysis: A Sourcebook of New Method, Baverly Hills: Sage Publication

Nasir, Haedar. (2019). Muhammadiyah Mencerdaskan dan Memajukan Bangsa. Diakses tanggal 10-2-2022 dari https://nasional.republika.co.id

Opp, Karl Dieter. (2009). Theory of Political Protest and Social Movement: a Multidiciplinary Introduction, Critique and Synthesis, London: Routhledge.

Peacock, James L. (1968). Purifying the Faith: The Muhammadiyah Movement in Indonesian Islam, terj. Andi Makmur Makkah, Yogyakarta: Suara Muhammadiyah.

Ritzers, George. (2004). Teori Sosiologi Klasik, Yogyakarta : Pustaka Pelajar.

Snow, David. (2004). Framing Process, Ideology and Discursive Fileds dalam Blackwel Companion to Social Movement. Massachusets : Balckwell Publishing.

Subarkah, Milna Abdullah. (2017). Muhammadiyah dan Amal Usaha di Bidang Pendidikan, Rausyan Fikr, 13 (2).

Usman, Abdul Hamid. (2019). Hak Milik atas Tanah Badan Hukum Persyarikatan Muhammadiyah, Jurnal Kepastian Hukum dan Keadilan, 1 (1). 
Utama, Abdul Alimun. (2017). Sejarah Dan Perkembangan Lembaga Pendidikan Muhammadiyah Di Kabupaten Sumbawa Nusa Tenggara Barat Tahun 19402014" PROFETIKA jurnal Pemikiran Islam, 18 (1)

Zarro, Mar'ati dkk.. (2020). Muhammadiyah Sebagai Gerakan Islam dan Pendidikan, FACTUM, 9 (4). 